\title{
ATP is dispensable for both miRNA- and Smaug-mediated deadenylation reactions
}

\author{
SHO NIINUMA and YUKIHIDE TOMARI \\ Institute of Molecular and Cellular Biosciences, The University of Tokyo, Bunkyo-ku, Tokyo 113-0032, Japan \\ Department of Computational Biology and Medical Sciences, The University of Tokyo, Bunkyo-ku, Tokyo 113-0032, Japan
}

\begin{abstract}
MicroRNAs (miRNAs), as well as the RNA-binding protein Smaug, recruit the CCR4-NOT deadenylase complex for shortening of the poly(A) tail. It has been believed that ATP is required for deadenylation induced by miRNAs or Smaug, based on the fact that the deadenylation reaction is blocked by ATP depletion. However, when isolated, neither of the two deadenylases in the CCR4NOT complex requires ATP by itself. Thus, it remains unknown why ATP is required for deadenylation by ribonucleoprotein complexes like miRNAs and Smaug. Herein we found that, in the absence of the ATP-regenerating system, ATP is rapidly consumed into AMP, a strong deadenylase inhibitor, in Drosophila cell lysate. Importantly, hydrolysis of AMP was sufficient to reactivate deadenylation by miRNAs or Smaug, suggesting that AMP accumulation, rather than ATP depletion, caused the inhibition of the deadenylation reaction. Our results indicate that ATP is dispensable for deadenylation induced by miRNAs or Smaug and emphasize caution in the use of ATP depletion methods.
\end{abstract}

Keywords: deadenylation; ATP; microRNA; Smaug; CCR4-NOT complex

\section{INTRODUCTION}

Controlling the length of the poly(A) tail, a stretch of adenylates at the $3^{\prime}$ end of eukaryotic mRNA, is crucial for precise regulation of gene expression and a wide range of biological processes. Shortening of the poly(A) tail, or deadenylation, is the first and rate-limiting step for the regular mRNA decay pathway (Chen and Shyu 2011; Wahle and Winkler 2013). Deadenylation can be accelerated by various RNA-binding proteins, which recruit deadenylase enzymes that catalyze the removal of adenylates from the poly(A) tail as well as other silencing factors (Chen and Shyu 2011; Du et al. 2016; Stowell et al. 2016). For example, microRNAs (miRNAs), a class of small RNA species, assemble the effector complex called RNA-induced silencing complex (RISC) by associating with a family of Argonaute (Ago) proteins (Bartel 2009; Kobayashi and Tomari 2016). miRNAs in RISC bind to complementary target mRNAs, inducing deadenylation and/or translational repression (Iwakawa and Tomari 2015; Jonas and Izaurralde 2015). Another example is Smaug, which binds to Smaug recognition elements (SREs) in specific maternal mRNAs including nanos and Hsp83 and induces their deadenylation and translational repression (Semotok et al. 2005; Zaessinger et al. 2006), thereby mediating maternal-to-zygotic transition in Drosophila embryos (Laver et al. 2015).

Corresponding author: tomari@iam.u-tokyo.ac.jp

Article is online at http://www.rnajournal.org/cgi/doi/10.1261/rna.060764. 117.
Both miRNAs and Smaug recruit the CCR4-NOT complex, which includes two deadenylase enzymes CCR4 and CAF1 (Iwakawa and Tomari 2015; Jonas and Izaurralde 2015; Laver et al. 2015). It has been reported that ATP is required for both miRNA-mediated and Smaug-mediated deadenylation reactions (Jeske et al. 2006; Iwasaki et al. 2009). Curiously, however, there is no apparent ATP-binding domain in CCR4 or CAF1 (Andersen et al. 2009; Wang et al. 2010a), and purified recombinant CCR4 and CAF1 proteins do not require ATP for catalyzing deadenylation (Maryati et al. 2015; Niinuma et al. 2016; Stowell et al. 2016). Thus, it remains enigmatic why ATP is required for deadenylation by miRNAs or Smaug.

Here, we reexamined the ATP requirement of miRNA- and Smaug-dependent deadenylation reactions using Drosophila cell lysate. As reported previously (Jeske et al. 2006; Iwasaki et al. 2009), both deadenylation reactions were drastically inhibited by exhaustion of ATP. However, we found that ATP consumption caused concurrent accumulation of AMP. Importantly, depletion of AMP was sufficient to reactivate the deadenylation reactions, even in the absence of ATP. These results suggest that AMP accumulation, not ATP consumption, blocks the deadenylation reactions. Our

(C) 2017 Niinuma and Tomari This article is distributed exclusively by the RNA Society for the first 12 months after the full-issue publication date (see http://rnajournal.cshlp.org/site/misc/terms.xhtml). After 12 months, it is available under a Creative Commons License (Attribution-NonCommercial 4.0 International), as described at http://creativecommons.org/licenses/by-nc/4.0/. 
findings resolve the apparent discrepancy in the ATP requirement by the CCR4-NOT complex and emphasize caution in the use of ATP depletion methods in vitro and in vivo.

\section{RESULTS}

\section{ATP is converted to AMP in Drosophila cell lysate}

It has been proposed that ATP is required for the miRNA-induced deadenylation reaction recapitulated in cell lysate from Drosophila embryos (Iwasaki et al. 2009). This conclusion is based on the observation that rapid poly(A) shortening was observed when the ATP level was maintained by creatine kinase $(\mathrm{CK})$ and creatine phosphate $(\mathrm{CP})$, which convert ADP into ATP (Fig. 1A), whereas deadenylation was significantly retarded when ATP was depleted from the lysate by hexokinase (HK) and glucose (Glc), which convert ATP into ADP (Fig. 1B). We first sought to reproduce this observation using lysate from Drosophila S2 cells expressing Flag-tagged Ago1, which is known to faithfully recapitulate miRNA-mediated deadenylation (Fukaya and Tomari 2011). Because RISC assembly per se requires ATP hydrolysis (Kawamata et al. 2009; Iwasaki et al. 2010), we first assembled Ago1-RISC with a let-7/let- $7^{*}$ miRNA duplex in the presence of $1 \mathrm{mM}$ ATP in S2 cell lysate, and then added a poly(A)-tailed target mRNA partially complementary to the let-7 sequence, together with either $\mathrm{CK}+\mathrm{CP}$ or $\mathrm{HK}+\mathrm{Glc}$ to maintain or deplete ATP, respectively (Fig. 1C). Consistent with the previous report, miRNA-mediated deadenylation was robust when ATP was regenerated by CK + CP but was strongly inhibited when ATP was depleted by HK + Glc (Fig. 1D). Interestingly, however, $\operatorname{poly}(\mathrm{A})$ shortening was also hindered without the addition of $\mathrm{HK}+\mathrm{Glc}$ (Fig. 1D), raising the possibility that S2 cell lysate alone consumed ATP.

To monitor ATP consumption, the miRNA-mediated deadenylation reaction in S2 cell lysate was repeated with a trace amount of $\left[\alpha^{-32} \mathrm{P}\right]$ ATP in addition to $1 \mathrm{mM}$ cold ATP at the beginning of the reaction, and the samples were then analyzed by thin-layer chromatography (TLC) (Fig. $1 \mathrm{E})$. The result showed that, even without the addition of $\mathrm{HK}+\mathrm{Glc}$, ATP was almost completely converted to AMP during the first 30-min incubation for RISC assembly, and this high AMP level was kept throughout the 60-min deadenylation reaction. In contrast, $\mathrm{CK}+\mathrm{CP}$ acted to maintain a high level of ATP during the deadenylation reaction, presumably via shifting the equilibrium among AMP, ADP, and ATP by actively converting ADP into ATP. Thus, the level of ATP correlates well with the efficiency of deadenylation.

\section{Depletion of AMP is sufficient to restore miRNA-mediated deadenylation}

The above observations are seemingly consistent with the idea that, as previously proposed, ATP is required for miRNAmediated deadenylation. However, given that S2 cell lysate
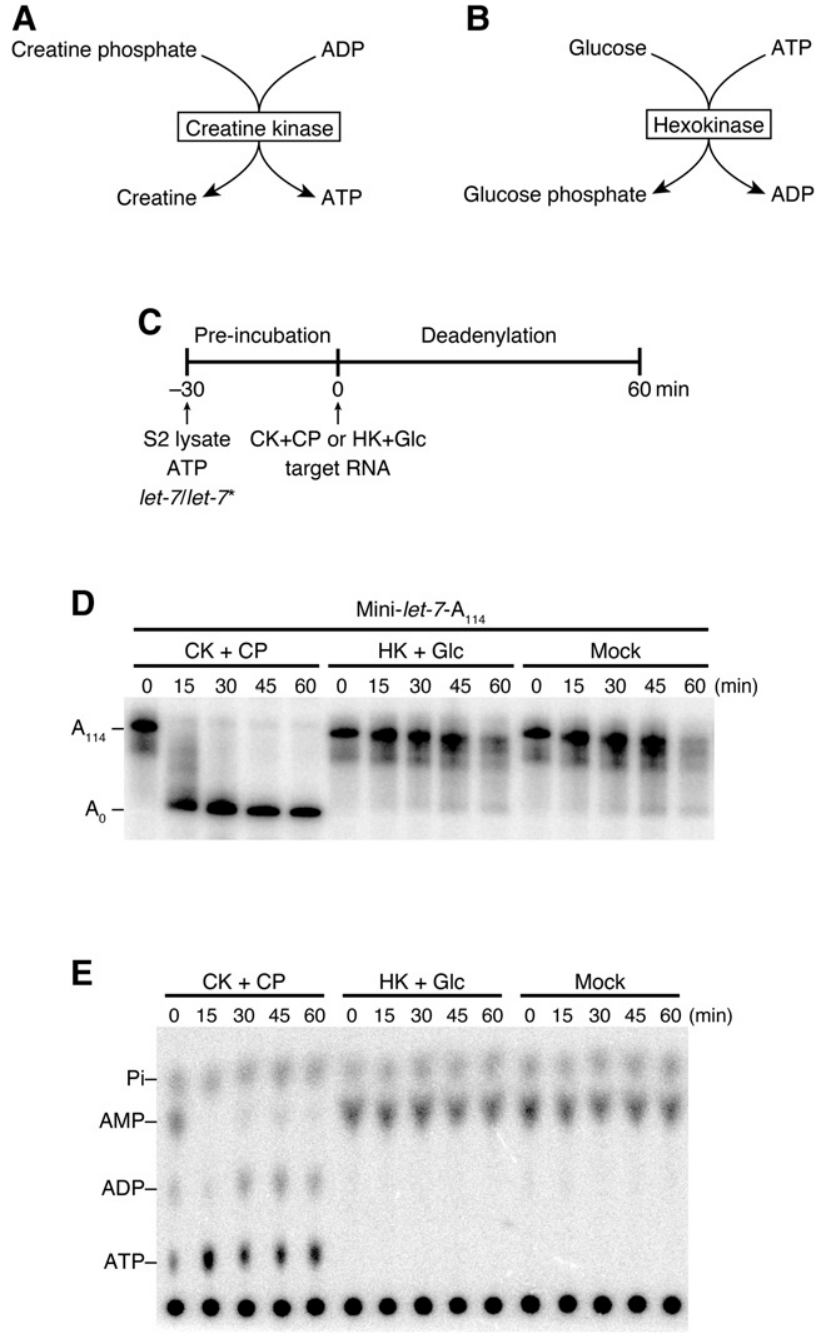

FIGURE 1. miRNA-mediated deadenylation and ATP consumption in Drosophila cell lysate. $(A, B)$ The reaction catalyzed by creatine kinase $(\mathrm{CK}, A)$ or hexokinase $(\mathrm{HK}, B)$. $(C)$ Experimental scheme in $D$ and $E$. RISC was first assembled in the mixture of S2 cell lysate overexpressing Flag-Ago1, 40× reaction mix (including a final concentration of 1 $\mathrm{mM}$ ATP), a trace amount of $\left[\mathrm{a}^{32} \mathrm{P}\right] \mathrm{ATP}$, and let-7/let- $7^{*}$ miRNA duplex for $30 \mathrm{~min}$. Then, CK + CP, HK + Glc, or water for Mock together with the cap-radiolabeled target RNA were added to the mixture. Deadenylation and ATP consumption were simultaneously monitored for $60 \mathrm{~min}$ in $D$ and $E$. $(D)$ miRNA-dependent deadenylation assay. Mini-let-7- $\mathrm{A}_{114}$ RNA with eight let-7 target sites and a 114-nt poly(A) tail was used as the substrate. Deadenylation occurred robustly in CK + CP but not in HK + Glc or Mock. (E) Thin-layer chromatography (TLC) assay for the analysis of ATP consumption. ATP was rapidly consumed into AMP in HK + Glc or even in Mock, whereas the ATP level was restored and maintained in $\mathrm{CK}+\mathrm{CP}$.

alone or together with HK + Glc consumed ATP and generated AMP, another possibility is that accumulation of AMP, rather than depletion of ATP, inhibited the miRNA-mediated deadenylation reaction; AMP is a reaction product of deadenylation and should in theory act as an effective inhibitor of the reaction. Indeed, the deadenylation activity of purified recombinant CCR4/CAF1 heterodimer, the catalytic core for miRNA-mediated deadenylation, was inhibited strongly 
A

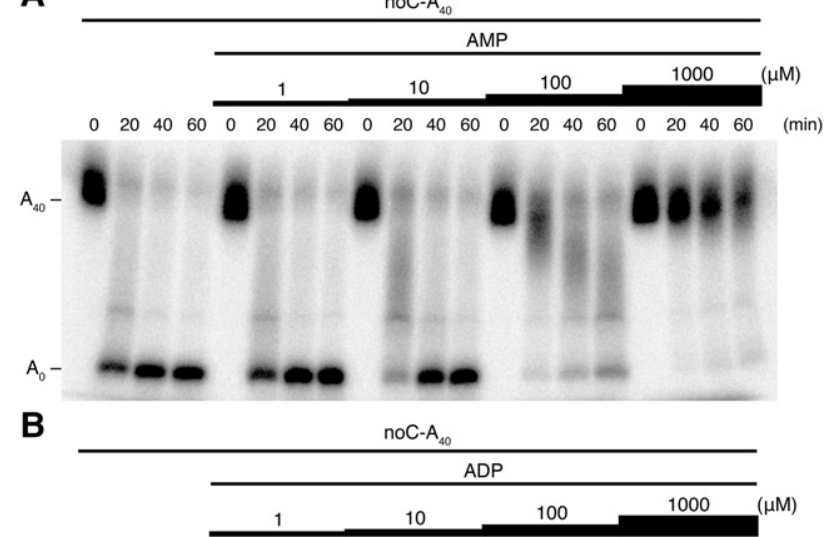

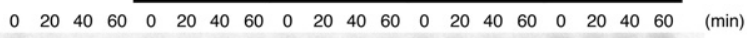

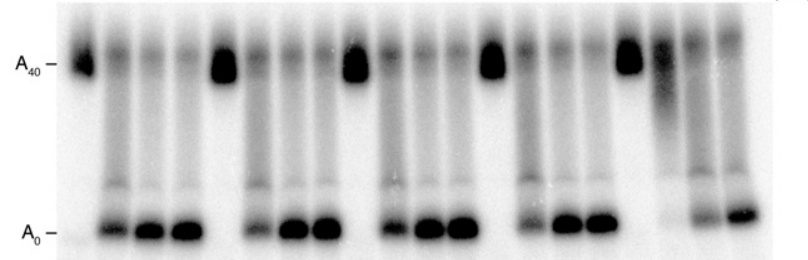

C

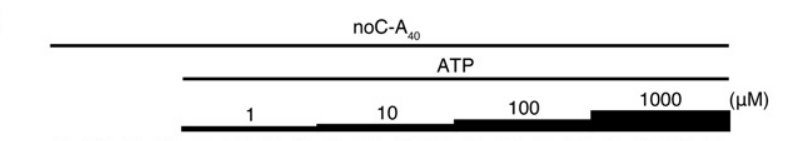

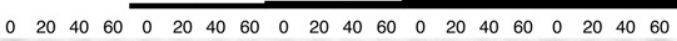

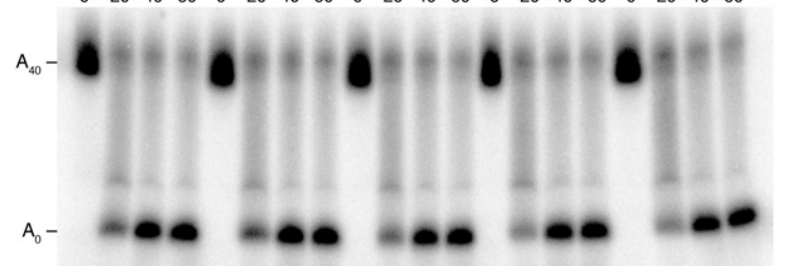

FIGURE 2. AMP strongly inhibits the deadenylation activity of recombinant CCR4/CAF1 heterodimer. $(A-C)$ Deadenylation of recombinant Drosophila CCR4/CAF1 heterodimer was monitored in the presence of increasing concentrations of $\operatorname{AMP}(A), \operatorname{ADP}(B)$, or ATP $(C)$. noC- $\mathrm{A}_{40}$ RNA with no internal cysteine residues and a 40-nt poly(A) tail (Niinuma et al. 2016) was used as the substrate.

by AMP, mildly by ADP, but not by ATP (Fig. 2A-C). Strong inhibition by AMP was also recently reported for human CNOT6L (hCcr4b) and CNOT7 (hCAF1) in their isolated forms (Zhang et al. 2016).

If it was AMP that inhibited the deadenylation reaction by miRNAs, then depletion of AMP should restore the activity. To test this hypothesis, we utilized $5^{\prime}$-nucleotidase, which catalyzes the hydrolysis of a mononucleotide (e.g., AMP) into a nucleoside (e.g., adenosine) and a phosphate for AMP depletion (Fig. 3A,B). As shown in Figure 3C, addition of $5^{\prime}$-nucleotidase instead of $\mathrm{CK}+\mathrm{CP}$ indeed stimulated poly(A) shortening, especially at later time points (Fig. 3C). Monitoring ATP consumption during the reaction revealed that $5^{\prime}$-nucleotidase gradually digested AMP and produced Pi (Fig. 3D), and the kinetics of AMP digestion correlated with that of the promotion of miRNA-mediated deadenylation (Fig. 3C,D). Preincubation of 5'-nucleotidase (i.e., pre- depletion of AMP) before the addition of the target mRNA further accelerated the deadenylation reaction (Supplemental Fig. S1). These results together suggest that, once RISC has been assembled in an ATP-dependent manner, depletion of AMP is sufficient to support miRNA-mediated deadenylation in S2 cell lysate.

\section{Depletion of AMP is sufficient to restore Smaug-mediated deadenylation}

Smaug is an RNA-binding protein that induces translational repression and degradation of specific maternal mRNAs including nanos in early Drosophila embryos (Laver et al. 2015). Smaug binds to Smaug recognition elements (SREs) in the target mRNAs and recruits the CCR4-NOT deadenylase complex (Laver et al. 2015). Just like miRNA-mediated deadenylation, Smaug-mediated deadenylation has also been proposed to require ATP (Jeske et al. 2006). To reexamine the ATP requirement in Smaug-mediated deadenylation, we prepared a Smaug target mRNA bearing a nanos SRE sequence in the $3^{\prime}$ UTR and a negative control mRNA with the SRE mutated, and confirmed that lysate from S2 cells overexpressing Flag-Smaug can faithfully recapitulate poly(A) shortening in an SRE-dependent manner (Supplemental Fig. S2). As reported previously, maintaining the ATP level

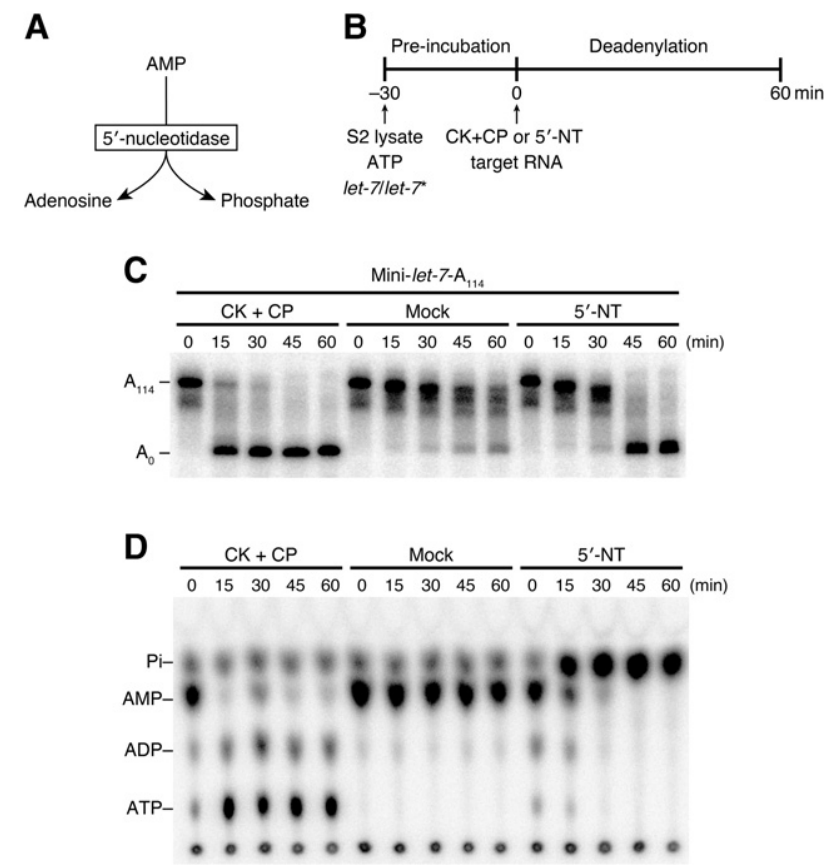

FIGURE 3. Depletion of AMP is sufficient to restore miRNA-mediated deadenylation. (A) The reaction catalyzed by $5^{\prime}$-nucleotidase $\left(5^{\prime}-\mathrm{NT}\right)$. $(B)$ Experimental scheme in $C$ and $D$. The experiment was conducted as in Figure 1C, except that $5^{\prime}$-NT was used. $(C)$ miRNA-mediated deadenylation assay. $5^{\prime}$-NT enhanced the deadenylation reaction, especially at later time points. (D) TLC assay for the analysis of ATP consumption. $5^{\prime}$-NT gradually converted AMP into Pi and adenosine, the kinetics of which correlated with that of deadenylation in $C$. 


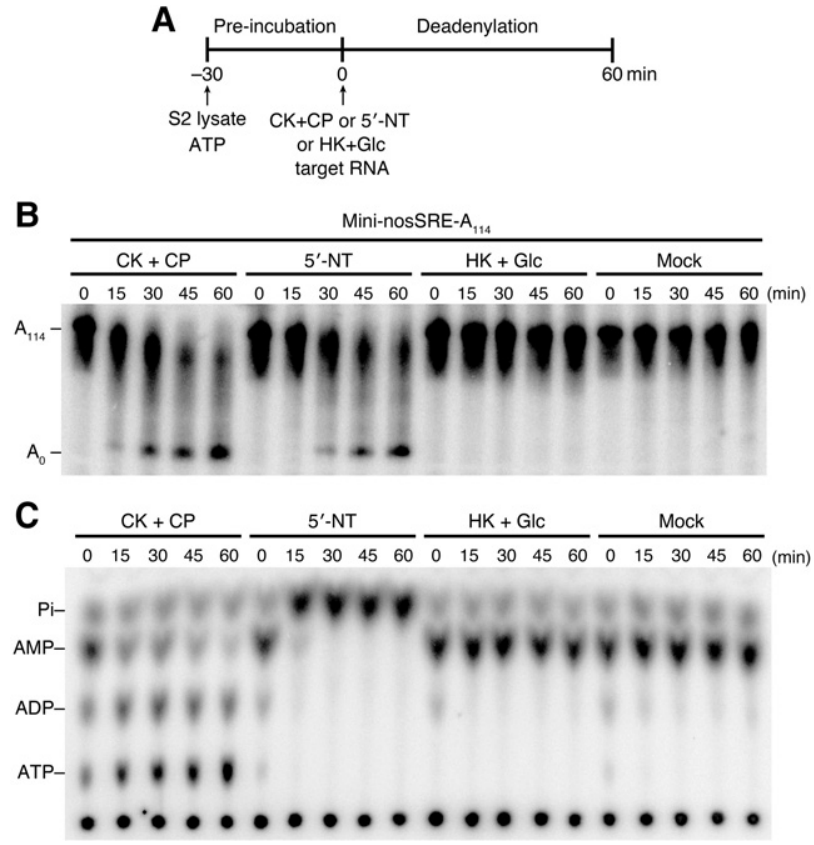

FIGURE 4. Depletion of AMP is sufficient to restore Smaug-mediated deadenylation. ( $A$ ) Experimental scheme in $B$ and $C$. The experiment was conducted as in Figures $1 \mathrm{C}$ and $3 \mathrm{~B}$, except that S2 lysate overexpressing Flag-Smaug and Mini-nosSRE- $\mathrm{A}_{114}$ target RNA was used and let-7/let-7* miRNA duplex was omitted. (B) Smaug-mediated deadenylation assay. Mini-nosSRE- $A_{114}$ RNA with nanos $3^{\prime}$ UTR including two SRE sites and a 114-nt poly(A) tail was used as the substrate. As is the case with miRNA-mediated deadenylation, Smaug-mediated deadenylation occurred robustly in $\mathrm{CK}+\mathrm{CP}$ or $5^{\prime}$-NT but not in HK + Glc or Mock. (C) TLC assay for the analysis of ATP consumption. AMP was accumulated in $\mathrm{HK}+$ Glc or Mock, but not in $\mathrm{CK}+\mathrm{CP}$ or $5^{\prime}$-NT.

by $\mathrm{CK}+\mathrm{CP}$ supported Smaug-mediated deadenylation, whereas depletion of ATP by $\mathrm{HK}+\mathrm{Glc}$ abolished it (Fig. 4A,B). Importantly, ATP was rapidly digested into AMP even without $\mathrm{HK}+\mathrm{Glc}$, and depletion of AMP by $5^{\prime}$-nucleotidase efficiently restored the deadenylation activity (Fig. $4 \mathrm{~A}-\mathrm{C})$. Thus, as is the case with miRNA-mediated deadenylation, ATP is dispensable for and AMP is inhibitory to Smaug-mediated deadenylation.

\section{DISCUSSION}

It has been believed that deadenylation mediated by either miRNAs or Smaug requires ATP, because the deadenylation reaction was strongly inhibited by consumption of ATP by $\mathrm{HK}+$ Glc but supported by maintaining the ATP level by CK + CP (Jeske et al. 2006; Iwasaki et al. 2009). Here, we found that in Drosophila cell lysate, ATP is degraded to AMP, a strong inhibitor for deadenylase enzymes (Fig. 2A; Zhang et al. 2016), regardless of the presence of HK + Glc. Notably, depletion of AMP by $5^{\prime}$-NT was sufficient to reactivate deadenylation, indicating that ATP per se is dispensable for deadenylation by miRNAs or Smaug. This result necessitates a reconsideration of the model for the molecular mechanism by which miRNAs, Smaug, and potentially other RNA-protein complexes mediate target mRNA deadenylation and decay.

Although our data show that the final effector step of miRNA-mediated deadenylation does not require ATP, the precedent RISC assembly step is known to require ATP hydrolysis (Kawamata et al. 2009; Yoda et al. 2010). More specifically speaking, an ATP-dependent action of the Hsc70/Hsp90 chaperone machinery is crucial for loading of miRNA duplexes into Ago proteins but not for ejecting one of the two small RNA strands from Ago (Iwasaki et al. 2010, 2015). Moreover, it is formally possible that ATP plays important roles in Ago-aided recruitment of downstream silencing factors including the CCR4/NOT complex-formation of "holo RISC"-as well as in deadenylationindependent translational repression mediated by miRNAs. Similarly, it was reported that assembly of the translational repression complex by Smaug is promoted by ATP (Jeske et al. 2011). Thus, multiple ATP-dependent steps in miRNA- and Smaug-mediated target silencing pathways are likely to exist, even though the deadenylation step itself does not require ATP.

$\mathrm{HK}+$ Glc is widely used as an effective tool for depleting ATP (Wang et al. 2010b; Chivasa and Slabas 2012; Sugi et al. 2015). Moreover, various chemical compounds and stress conditions are known to cause acute ATP depletion by either inducing ATP consumption or inhibiting ATP synthesis (Hawley et al. 2010; Ishimoto et al. 2012). The effects of such cellular ATP depletion are often associated with the activation of AMP-activated protein kinase (AMPK) or AMP deaminase (AMPD) by the production of AMP, rather than exhaustion of ATP (Hawley et al. 2010; Johnson et al. 2013). Our results reinforce the idea that caution should be exercised when depleting ATP in vitro and in vivo.

\section{MATERIALS AND METHODS}

\section{General methods}

Preparation of lysis buffer [30 mM Hepes-KOH ( $\mathrm{pH}$ 7.4), $100 \mathrm{mM}$ $\mathrm{KOAc}$, and $2 \mathrm{mM} \mathrm{Mg}(\mathrm{OAc})_{2}$ ], $2 \times$ proteinase $\mathrm{K}$ buffer $[200 \mathrm{mM}$ Tris-Cl (pH 7.5), $25 \mathrm{mM}$ EDTA (pH 8.0), $300 \mathrm{mM} \mathrm{NaCl}$, and $2 \% \mathrm{w} / \mathrm{v} \mathrm{SDS}]$, and formamide loading dye $[98 \% \mathrm{w} / \mathrm{v}$ deionized formamide, $10 \mathrm{mM}$ EDTA ( $\mathrm{pH} 8.0$ ), 0.025\% w/v xylene cyanol, and $0.025 \% \mathrm{w} / \mathrm{v}$ bromophenol blue] was previously described (Haley et al. 2003). Of note, $40 \times$ reaction mix has been described in Haley et al. (2003), which was used with a slight modification in this study [ $50 \mu \mathrm{L}$ of water, $20 \mu \mathrm{L}$ of $500 \mathrm{mM}$ creatine monophosphate (Sigma), $2 \mu \mathrm{L}$ of $1 \mathrm{M}$ DTT, $1 \mu \mathrm{L}$ of $40 \mathrm{U} / \mu \mathrm{L}$ RNasin plus (Promega), $4 \mu \mathrm{L}$ of $100 \mathrm{mM}$ ATP, $6 \mu \mathrm{L}$ of $2 \mathrm{U} / \mu \mathrm{L}$ creatine phosphokinase (Cal-Biochem), $16 \mu \mathrm{L}$ of $1 \mathrm{M} \mathrm{KOAc}$, and $2.24 \mu \mathrm{L}$ of $500 \mathrm{mM}$ $\left.\mathrm{Mg}(\mathrm{OAc})_{2}\right]$. 


\section{Preparation of S2 cell lysate}

Preparation of S2 cell lysate was previously described (Fukaya et al. 2014). Briefly, collected S2 cells were washed once by PBS and resuspended in an equal volume of hypotonic lysis buffer [10 $\mathrm{mM}$ Hepes-KOH (pH 7.4), $10 \mathrm{mM} \mathrm{KOAc,} 1.5 \mathrm{mM} \mathrm{Mg}(\mathrm{OAc})_{2}, 5 \mathrm{mM}$ DTT, and $1 \times$ EDTA-free protease inhibitor cocktail (Roche)]. After $15 \mathrm{~min}$ on ice, the cells were vortexed for $30 \mathrm{sec}$ and centrifuged $17,000 \mathrm{~g}$ for $20 \mathrm{~min}$ at $4^{\circ} \mathrm{C}$. The supernatant was collected and used for the experiments.

\section{Plasmid construction}

pUC57-Mini-nosSRE- $A_{114}$ and pUC57-Mini-nosSREmut- $A_{114}$

For preparing pUC57-Mini-nosSRE-A114, two DNA oligos, 5'TAGGCGATCGCTCGAAGAGGGCGAATCCAGCTCTGGAGCA GAGGCTCTGGCAGCTTTTGCAGCGTTTATATAACATGAAAT ATATATACGCATTCCGATCAAA-3' ${ }^{\prime}$ and $5^{\prime}$-AGGCGGCCAGCGG CCTCTAAATCTCTTTAAAATCGAACGCGCCAGGCGCTATTT AAACGTTACTATCTATCTATCTGGTTAACCCAGCTTTGATC GGAATGCG-3', were annealed and amplified by PCR. The PCR product was inserted by using Infusion HD (Takara) into pUC57 digested by XhoI and NotI. pUC57-Mini-nosSREmut- $\mathrm{A}_{114}$ was prepared as pUC57-Mini-nosSRE- $\mathrm{A}_{114}$, except that the following DNA oligos were used: 5'-TAGGCGATCGCTCGAAGAGGGCG AATCCAGCTCTGGAGCAGAGGCTCTCGCAGCTTTTGCAGCG TTTATATAACATGAAATATATATACGCATTCCGATCAAA- ${ }^{\prime}$ and 5'-AGGCGGCCAGCGGCCTCTAAATCTCTTTAAAATCGAACGC GCGAGGCGCTATTTAAACGTTACTATCTATCTATCTGGTTAA CCCAGCTTTGATCGGAATGCG-3'. The sequences of these DNA oligos were designed based on Jeske et al. (2006).

\section{Preparation of the target RNAs}

Mini-let-7- $A_{114}$, Mini-nosSRE- $A_{114}$, and Mini-nosSREmut- $A_{114}$

Mini-let-7-A $\mathrm{A}_{114}$, Mini-nosSRE- $\mathrm{A}_{114}$, and Mini-nosSREmut- $\mathrm{A}_{114}$ RNAs were in vitro transcribed by T7-Scribe Standard RNA IVT Kit (CELLSCRIPT) from pUC57-Mini-let-7-A ${ }_{114}$, pUC57-MininosSRE- $\mathrm{A}_{114}$, and pUC57-Mini-nosSREmut- $\mathrm{A}_{114}$, respectively, as previously described (Fukaya and Tomari 2011).

noC $-A_{40}$

Based on the noC RNA series previously reported (Niinuma et al. 2016), DNA fragments were amplified by three-way overlapping PCR using primers $5^{\prime}$-GGTGAGAGTGAGTAGTGTAGTATTGGT AGTTGTATTAGAGTGAGGTTGTGGTTTGTGGGT-3', 5' -CGTAA TACGACTCACTATAGGTGAGAGTGAGTAGTGTAGTATTGG-3', and $5^{\prime}$-TTTTTTTTTTTTTTTTTTTTTTTTTTTTTTTTTTTTTTTT ACCCACAAACCACAACCTC- $3^{\prime}$ and used for in vitro transcription by T7-Scribe Standard RNA IVT Kit (CELLSCRIPT). All target RNAs were radiolabeled by using ScriptCap $\mathrm{m}^{7} \mathrm{G}$ Capping System (CELLSCRIPT) and $\left[\alpha^{-}{ }^{32} \mathrm{P}\right]$ GTP (PerkinElmer).

\section{Deadenylation assay and ATP consumption assay}

The deadenylation assay in S2 cell lysate was performed as described previously (Fukaya et al. 2014) with slight modifications. Typically,
$7.5 \mu \mathrm{L}$ of lysate from S2 cells overexpressing Flag-Agol or FlagSmaug, $4.5 \mu \mathrm{L}$ of $40 \times$ reaction mix without creatine kinase or creatine monophosphate, $1.5 \mu \mathrm{L}$ of $500 \mathrm{nM}$ let-7/let-7* duplex (replaced with lysis buffer for Smaug-related assays), and $2 \mu \mathrm{L}$ of $\left[a-{ }^{32} \mathrm{P}\right]$ ATP (PerkinElmer) were incubated at $25^{\circ} \mathrm{C}$. Then, $2 \mu \mathrm{L}$ of a mixture of $0.35 \mathrm{U} / \mu \mathrm{L}$ creatine kinase (Millipore) and $300 \mathrm{mM}$ creatine monophosphate (Sigma), $1 \mu \mathrm{L}$ of $2 \mathrm{U} / \mu \mathrm{L}$ hexokinase (Sigma) and $2 \mu \mathrm{L}$ of $200 \mathrm{mM}$ glucose, or $2 \mu \mathrm{L}$ of $100 \mathrm{ng} / \mu \mathrm{L} 5^{\prime}$-nucleotidase (human CD73; R\&D Systems) was added to the corresponding reactions and incubated at $25^{\circ} \mathrm{C}$. At the same time (Figs. 1, 3, 4) or after a 30-min incubation (Supplemental Fig. S1), $1.5 \mu \mathrm{L}$ of $\sim 5 \mathrm{nM}$ $5^{\prime}$ cap-radiolabeled target RNA was added, the total volume was adjusted to $20 \mu \mathrm{L}$ by water, and the reaction was further incubated at $25^{\circ} \mathrm{C}$. At each time point indicated, $2.8 \mu \mathrm{L}$ and $1 \mu \mathrm{L}$ of the reaction mixture were taken for the analysis of deadenylation and ATP consumption, respectively. The $2.8 \mu \mathrm{L}$ aliquots were analyzed for deadenylation as described previously (Fukaya et al. 2014). The $1 \mu \mathrm{L}$ aliquots were mixed with $4 \mu \mathrm{L}$ of formamide loading dye, incubated at $95^{\circ} \mathrm{C}$ for $3 \mathrm{~min}$, and immediately chilled on ice. Then, $2 \mu \mathrm{L}$ of the mixture was spotted on a polyethyleneimine-cellulose plate for thinlayer chromatography as previously described (Niinuma et al. 2016).

\section{Deadenylation assay with recombinant CCR4/CAF1 heterodimer}

Preparation of recombinant Drosophila CCR4/CAF1 heterodimer and deadenylation assay with the enzyme was previously described (Niinuma et al. 2016). Deadenylation reaction to estimate the inhibitory effect by AMP, ADP, and ATP contained $4.2 \mu \mathrm{L}$ of water, $3 \mu \mathrm{L}$ of $1.5 \mu \mathrm{M}$ CCR4/CAF1 heterodimer, $3 \mu \mathrm{L}$ of $5 \times$ lysis buffer, $1.5 \mu \mathrm{L}$ $10 \mathrm{mM}$ DTT, $0.3 \mu \mathrm{L}$ of $40 \mathrm{U} / \mu \mathrm{L}$ RNasin plus (Promega), $1.5 \mu \mathrm{L}$ of $\sim 5 \mathrm{nM} \mathrm{noC}-\mathrm{A}_{40}$, and $1.5 \mu \mathrm{L}$ of $10 \times \mathrm{AMP}, \mathrm{ADP}$, or ATP. The mixture was incubated at $25^{\circ} \mathrm{C}$, and $3 \mu \mathrm{L}$ of it was collected at each time point. The equal volume of formamide loading dye was added to the collected sample immediately. Then, the sample was electrophoresed on $5 \%$ denaturing polyacrylamide gel and analyzed by PhosphoImager (Typhoon FLA 7000, GE Healthcare).

\section{SUPPLEMENTAL MATERIAL}

Supplemental material is available for this article.

\section{ACKNOWLEDGMENTS}

We thank Takashi Fukaya for his help in plasmid construction. We also thank members of the Tomari laboratory for advice, discussion, and critical comments on the manuscript. This work was supported in part by a Grant-in-Aid for Scientific Research (A) to Y.T. (grant number 15H02382) from the Japan Society for the Promotion of Science. S.N. is a recipient of a JSPS Research Fellowship for Young Scientists (grant number 14J08195).

Received January 11, 2017; accepted February 24, 2017.

\section{REFERENCES}

Andersen KR, Jonstrup AT, Van LB, Brodersen DE. 2009. The activity and selectivity of fission yeast Pop2p are affected by a high affinity for $\mathrm{Zn}^{2+}$ and $\mathrm{Mn}^{2+}$ in the active site. RNA 15: 850-861. 
Bartel DP. 2009. MicroRNAs: target recognition and regulatory functions. Cell 136: 215-233.

Chen CY, Shyu AB. 2011. Mechanisms of deadenylation-dependent decay. Wiley Interdiscip Rev RNA 2: 167-183.

Chivasa S, Slabas AR. 2012. Plant extracellular ATP signalling: new insight from proteomics. Mol Biosyst 8: 445-452.

Du H, Zhao Y, He J, Zhang Y, Xi H, Liu M, Ma J, Wu L. 2016. YTHDF2 destabilizes $\mathrm{m}^{6} \mathrm{~A}$-containing RNA through direct recruitment of the CCR4-NOT deadenylase complex. Nat Commun 7: 12626.

Fukaya T, Tomari Y. 2011. PABP is not essential for microRNA-mediated translational repression and deadenylation in vitro. $E M B O J$ 30: 4998-5009.

Fukaya T, Iwakawa HO, Tomari Y. 2014. MicroRNAs block assembly of eIF4F translation initiation complex in Drosophila. Mol Cell 56: 67-78.

Haley B, Tang G, Zamore PD. 2003. In vitro analysis of RNA interference in Drosophila melanogaster. Methods 30: 330-336.

Hawley SA, Ross FA, Chevtzoff C, Green KA, Evans A, Fogarty S, Towler MC, Brown LJ, Ogunbayo OA, Evans AM, et al. 2010. Use of cells expressing $\gamma$ subunit variants to identify diverse mechanisms of AMPK activation. Cell Metab 11: 554-565.

Ishimoto T, Lanaspa MA, Le MT, Garcia GE, Diggle CP, Maclean PS, Jackman MR, Asipu A, Roncal-Jimenez CA, Kosugi T, et al. 2012. Opposing effects of fructokinase $\mathrm{C}$ and $\mathrm{A}$ isoforms on fructoseinduced metabolic syndrome in mice. Proc Natl Acad Sci 109: $4320-4325$.

Iwakawa HO, Tomari Y. 2015. The functions of microRNAs: mRNA decay and translational repression. Trends Cell Biol 25: 651-665.

Iwasaki S, Kawamata T, Tomari Y. 2009. Drosophila argonautel and argonaute2 employ distinct mechanisms for translational repression. Mol Cell 34: 58-67.

Iwasaki S, Kobayashi M, Yoda M, Sakaguchi Y, Katsuma S, Suzuki T, Tomari Y. 2010. Hsc70/Hsp90 chaperone machinery mediates ATP-dependent RISC loading of small RNA duplexes. Mol Cell 39: 292-299.

Iwasaki S, Sasaki HM, Sakaguchi Y, Suzuki T, Tadakuma H, Tomari Y. 2015. Defining fundamental steps in the assembly of the Drosophila RNAi enzyme complex. Nature 521: 533-536.

Jeske M, Meyer S, Temme C, Freudenreich D, Wahle E. 2006. Rapid ATP-dependent deadenylation of nanos mRNA in a cell-free system from Drosophila embryos. J Biol Chem 281: 25124-25133.

Jeske M, Moritz B, Anders A, Wahle E. 2011. Smaug assembles an ATPdependent stable complex repressing nanos mRNA translation at multiple levels. $E M B O J$ 30: 90-103.

Johnson RJ, Nakagawa T, Sanchez-Lozada LG, Shafiu M, Sundaram S, Le M, Ishimoto T, Sautin YY, Lanaspa MA. 2013. Sugar, uric acid, and the etiology of diabetes and obesity. Diabetes 62: 3307-3315.
Jonas S, Izaurralde E. 2015. Towards a molecular understanding of microRNA-mediated gene silencing. Nat Rev Genet 16: 421-433.

Kawamata T, Seitz H, Tomari Y. 2009. Structural determinants of miRNAs for RISC loading and slicer-independent unwinding. Nat Struct Mol Biol 16: 953-960.

Kobayashi H, Tomari Y. 2016. RISC assembly: coordination between small RNAs and Argonaute proteins. Biochim Biophys Acta 1859: $71-81$.

Laver JD, Marsolais AJ, Smibert CA, Lipshitz HD. 2015. Regulation and function of maternal gene products during the maternal-to-zygotic transition in Drosophila. Curr Top Dev Biol 113: 43-84.

Maryati M, Airhihen B, Winkler GS. 2015. The enzyme activities of Caf1 and Ccr4 are both required for deadenylation by the human Ccr4Not nuclease module. Biochem J 469: 169-176.

Niinuma S, Fukaya T, Tomari Y. 2016. CCR4 and CAF1 deadenylases have an intrinsic activity to remove the post-poly(A) sequence. RNA 22: 1550-1559.

Semotok JL, Cooperstock RL, Pinder BD, Vari HK, Lipshitz HD, Smibert CA. 2005. Smaug recruits the CCR4/POP2/NOT deadenylase complex to trigger maternal transcript localization in the early Drosophila embryo. Curr Biol 15: 284-294.

Stowell JA, Webster MW, Kögel A, Wolf J, Shelley KL, Passmore LA. 2016. Reconstitution of targeted deadenylation by the Ccr4-not complex and the YTH domain protein Mmil. Cell Rep 17: 1978-1989.

Sugi H, Chaen S, Akimoto T, Minoda H, Miyakawa T, Miyauchi Y, Tanokura M, Sugiura S. 2015. Electron microscopic recording of myosin head power stroke in hydrated myosin filaments. Sci Rep 5: 15700.

Wahle E, Winkler GS. 2013. RNA decay machines: deadenylation by the Ccr4-not and Pan2-Pan3 complexes. Biochim Biophys Acta 1829: 561-570.

Wang H, Morita M, Yang X, Suzuki T, Yang W, Wang J, Ito K, Wang Q, Zhao C, Bartlam M, et al. 2010a. Crystal structure of the human CNOT6L nuclease domain reveals strict poly(A) substrate specific-

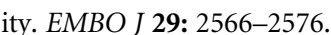

Wang W, Wu J, Bernard K, Li G, Wang G, Bevensee MO, Kirk KL. 2010b. ATP-independent CFTR channel gating and allosteric modulation by phosphorylation. Proc Natl Acad Sci 107: 3888-3893.

Yoda M, Kawamata T, Paroo Z, Ye X, Iwasaki S, Liu Q, Tomari Y. 2010. ATP-dependent human RISC assembly pathways. Nat Struct Mol Biol 17: 17-23.

Zaessinger S, Busseau I, Simonelig M. 2006. Oskar allows nanos mRNA translation in Drosophila embryos by preventing its deadenylation by Smaug/CCR4. Development 133: 4573-4583.

Zhang Q, Yan D, Guo E, Ding B, Yang W, Liu R, Yamamoto T, Bartlam M. 2016. Structural basis for inhibition of the deadenylase activity of human CNOT6L. FEBS Lett 590: 1270-1279. 

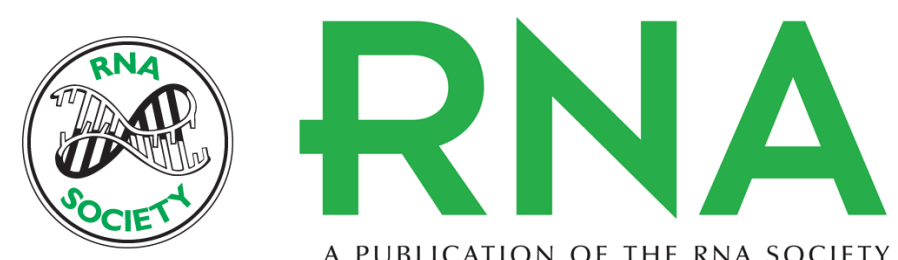

A PUBLICATION OF THE RNA SOCIETY

\section{ATP is dispensable for both miRNA- and Smaug-mediated deadenylation reactions}

Sho Niinuma and Yukihide Tomari

RNA 2017 23: 866-871 originally published online March 1, 2017

Access the most recent version at doi:10.1261/rna.060764.117

\section{Supplemental http://rnajournal.cshlp.org/content/suppl/2017/03/01/rna.060764.117.DC1 \\ Material}

References This article cites 32 articles, 11 of which can be accessed free at: http://rnajournal.cshlp.org/content/23/6/866.full.html\#ref-list-1

Creative This article is distributed exclusively by the RNA Society for the first 12 months after the Commons License full-issue publication date (see http://rnajournal.cshlp.org/site/misc/terms.xhtml). After 12 months, it is available under a Creative Commons License (Attribution-NonCommercial 4.0 International), as described at http://creativecommons.org/licenses/by-nc/4.0/.
Email Alerting Receive free email alerts when new articles cite this article - sign up in the box at the Service top right corner of the article or click here.

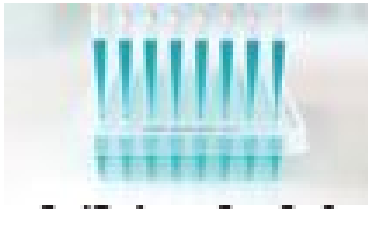

\section{Providing Precise Solutions for} your research.

To subscribe to $R N A$ go to:

http://rnajournal.cshlp.org/subscriptions 